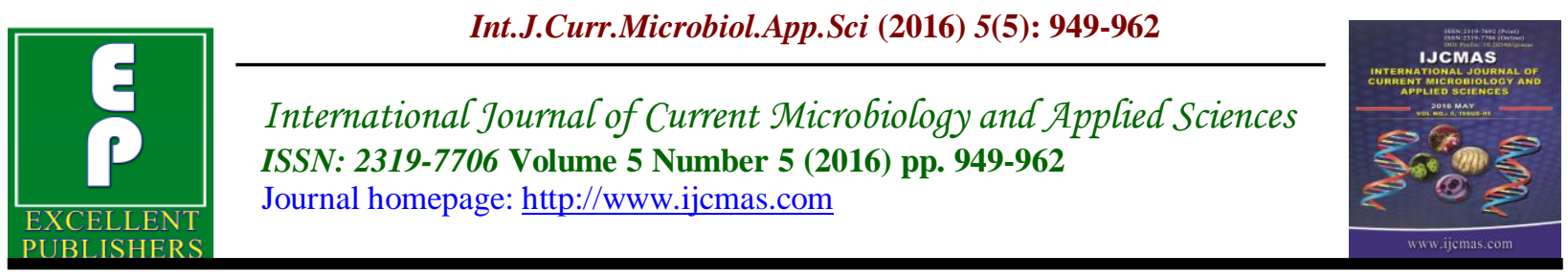

Original Research Article

http://dx.doi.org/10.20546/ijcmas.2016.505.100

\title{
Evaluation of Plant Extracts and Essential Oils for the Control of Sudden Wilt Disease of Watermelon Plants
}

\author{
Hosam M. Awad* \\ Agric. Botany Dept., Fac. of Agriculture, Minufiya Univ., Egypt \\ *Corresponding author
}

\section{Keywords \\ Phytoextract, Aqueous Extract, Essential Plant Oil, Fungicide, Sudden Wilt, Watermelon, Monosporascus cannonballus.}

\begin{tabular}{l}
\hline Article Info \\
\hline Accepted: \\
15 March 2016 \\
Available Online: \\
10 May 2016
\end{tabular}

\section{A B S T R A C T}

Recently, in different countries of the world, attention has been paid towards exploitation of higher plant products as novel chemotherapeutants in plant protection. The antifungal activity of aqueous extracts of Garlic (Allium sativum, L.); Black pepper (Piper nigrum L.); Black cumin (Nigella) (Nigella sativa L.); Cinnamon (Cinnamum zeylanicum);Clove bud (Dianthus caryphlus L.); and Ginger (Zingber officinalis, L.) was investigated for controlling Monosporascus cannonballus sudden wilt disease of watermelon plants at two concentrations i.e., 1 and $5 \%$. The pathogenic fungus isolates have been isolated from infected plant parts and identified on the basis of their morphological and cultural characteristics. All the plant extracts showed considerable diminution of sudden wilt disease infection on watermelon plants under greenhouse conditions. Garlic followed by Clove bud extracts were the most effective in disease control. Significant differences were noticed between all tested plant extracts and their used concentrations in infested pots by three highly pathogenic isolates. Also, essentialoil of Garlic, Cinnamon bud, Marjoram (Origanum majorana L.), and Black pepper were used in controlling the same disease of watermelon plants. Drenching soil with plant oils suspension in all used concentrations decreased sudden wilt disease parameters of watermelon plants cv. Giza 1 that sown in pots infested with one of the three virulent isolates of $M$. cannonballs in comparison to control. Suspensions of Garlic oil followed by Black pepper oil were affected and decreased disease parameters as well as the inhibition of disease were increased by increasing of plant oil concentrations. Comparative studies were done in controlling sudden wilt disease of watermelon plants using three chemical fungicides, i.e. Rizolex T., Rofral and Bellis. The fungicide Bellis was more effective in controlling disease infection; also increasing fungicide concentration up to $1000 \mathrm{ppm}$ was more effective in disease control. The application of botanical extracts for disease management could be less expensive, easily available, nonpolluting and eco-friendly.

\section{Introduction}

Watermelon (Citrullus lanatus L.), is one of the most important vegetables in Egypt.
Watermelon is liable to be attacked by many different pathogens causing large losses in 
crop i.e., wilt and many other diseases. Wilt disease caused by many soil pathogens, one of these pathogens causing sudden wilt, vine collapse / root rot and vine decline disease that caused by the fungus Monosporascus cannonballs (Bruton et al., 2000). Suddenwilt disease causes crop losses in watermelon up to $100 \%$ losses (Martyn and Miller, 1996). Last decades M. cannonballus was reported in several countries region i.e., Tunisia (Martyn et al., 1994), Mexico (Martyn et al., 1996), Saudia Arabia (Karlatti et al., 1997), Italy (Gennari et al., 1999), Egypt (El-Desouky and El-Wakil, 2003) and (Khalifa et al., 2008), Iran (Sarpeleh, 2008) and China (Suqin and Bin, 2010).

The pathogen infects watermelon plants at the end of vegetative stage and cause severe damage of plants due to death of plant. The control of $M$. cannonballus is still based upon multiple applications of fungicides during the flowering and fruiting periods. Currently, there is a world wide trend to explore new alternatives to synthetic fungicides in order to minimize the risks associated with the development of populations insensitive to these chemical compounds and also comply with food safety standards. Furthermore, the use of some synthetic chemicals to control fungal diseases is restricted due to their high toxicity, long degradation periods and environmental pollution. The use of natural compounds as plant extracts and plant oils may be an alternative to fungicides to control plant pathogens. (Tsair-Bor and Shang-Tzen, 2008).

Therefore, the present investigation was aimed to study pathogenicity test for different isolates of the fungus $M$. cannonballs to determine the most pathogenic isolates, as well as using of some plant extracts and plant oils for control sudden wilt disease of watermelon under greenhouse conditions, instead of a lot of problems threaten to limit the continued use of fungicides.

\section{Materials and Methods}

Isolation of the causal organism of sudden wilt disease of watermelon plants was done from diseased plants showing sudden wilt symptoms collected from open fields of different growing locations in different governorates in Egypt i.e., Minufiya (ElSadat), Ismailiya (El-Kassassin), Behaira (El-Noubariya), Dakahliya (Belkas), Alexandria (El-Amriya), Sinai (El-Arish). All procedures of isolation and purification were done at the laboratories of plant pathology, Faculty of Agriculture, Minufiya University during 2013 and 2014 seasons. Pure cultures of the growing fungi were examined morphologically and microscopically characteristics of mycelia, perithecia, asci and spores as described by Pollack and Uecker, 1974 in order to identify them at Agric. Bot. Dept., Fac. of Agric., Minufiya Univ.

\section{Plant Extracts}

Because a lot of problems threaten to limit the continued use of fungicides; these experiments conducted to use environmentally safe alternative methods of fungal control as aqueous extract of many allelopathic plants. All powder plants of this study were collected and identified at the Herbarium of the Dept. of Cogecutical and Medical plants, Fac. of Pharmaceutical Sciences and Industries, Future University, New Cairo. Aqueous extracts of plant samples were prepared according to Mutwally et al., 2010. Six plant materials were used for preparation of extracts, i.e., Garlic, Black pepper, Clove bud, Black cumin, Cinnamon and Ginger. 


\section{Pathogenicity Tests}

Pathogenicity tests were conducted in greenhouse of the Faculty of Agriculture, Minufiya University using six isolates of the fungus $M$. cannonballus representative the six governorates of isolation ;inoculums was prepared on sorghum grains medium. Sorghum grains were covered with water in glass bottle $\left(250 \mathrm{~cm}^{3}\right.$ in size $)$ and autoclaved, then inoculated with each of the 6 isolates then incubated at $28^{\circ} \mathrm{C}$ for two weeks. Black plastic pots $(25 \mathrm{~cm}$ in diameter) were filled with mixture of sand and field soil $(1: 1, \mathrm{v}$ : v). Mixture were mixed thoroughly with the growing fungus at the rate of $20 \mathrm{gm}$ of inoculums /pot in the lower half of pot and then the pot filled with mixture of soil and sand in the upper half. (Martyn et al., 1996). Six seeds of watermelon cv. Giza 1 were sown in each pot. Five pots were used as replicates of each treatment. Five pots without fungus inoculums were seeded and served as a control. Pots were irrigated as needed and fertilized weekly with NPK diluted solutions. The experiment was noticed weekly and examined \& calculated 8-9 weeks when the plant root system was infected and disease symptoms were appeared. Pathogenic fungi re-isolated from typical sudden wilt symptoms, produced by artificial inoculation, and then they were examined microscopically and compared with the original isolates that used in inoculation of pathogenicity tests. Disease incidence assessment in different treatments was carried out through percentage of sudden wilt plants (SW \%) and disease severity index DI (according to the type of discoloration epidermal tissues) observed on roots stalk of inoculated watermelon plants as described by Aegerter et al., 2000, as following : rating roots was scale of 0 to 4 as follows : $0=$ no symptoms, $1=$ few tan lesions, $2=$ extensive $\tan$ lesions and necrosis of smallest roots, $3=$ extensive tan lesions, perithecia, necrosis of small and medium roots, $4=$ completely withered, necrotic, dead roots. Disease parameters were recorded after 70 days and measured in all treatments in this study. Disease severity index (DI) was recorded as follows:

Disease Index (DI) $=$ [disease class $\mathrm{x}$ No. plants in class) $\mathrm{x} 100 \div$ (total plants) $\mathrm{x} 4]$.

Also the number of surviving plants was recorded at the end of the growing period.

\section{Statistical Analysis}

Data obtained were subjected to the proper statistical analysis for each experiment using the MSTAT statistical software. Comparisons were made following Fishers LSD (0.05).

\section{Control Experiments}

\section{Fungicides}

Three fungicdes, i.e., Rizolex T. ( Tolcofosmethy $1+$ thiram, 50\% WP); Rofral (Iprodione, $50 \% \quad \mathrm{WP}$ ) and Bellis (Pyralostrobin + Boscalid 38\% WC) were used for controlling sudden wilt disease of watermelon under greenhouse conditions at concentrations of 100,500 and $1000 \mathrm{ppm}$. Inoculums of three virulent isolates, i.e., 1, 3 and 6 were prepared as mentioned before. All fungicides were applied as soil drench. Six seeds of watermelon susceptible cv. Giza 1 were sown in each infested pot (25 $\mathrm{cm}$ in diameter); the pots were irrigated with fungicides concentrations individually per pot at two weeks intervals. The control treatment was made in the same mode but the pots didn't infestedand irrigated with water. Percentage of sudden wilt plants and disease severity index (\%) were calculated after 70 days after sowing. Data were tabulated and statistically analyzed as mentioned before. 


\section{Plant Extracts}

\section{In vitro Studies}

The plant extracts were adopted with $3 \mathrm{ml}$ from each extract individual at $(1,5$ and $10 \%$ concentration) to the solid media on the surface of the media in Petri dish, then the extract well spreaded on the surface tell complete absorption into media to test their effect on the linear growth of the fungus isolates. Four replicates of each treatment were used. The plates were inoculated with the inoculum disk $(4 \mathrm{~mm})$ of $M$. cannonballus isolates (1, 3 and 6$)$ at the center of the dish and linear growth measured when the control treatments were completed.

\section{In vivo Studies}

To study the plant extracts effect for controlling the sudden wilt disease of watermelon under greenhouse conditions; two concentrations $1 \%$ and $5 \%$ of the aqueous extracts were tested to control the disease. Inoculums of the most virulent three aggressive isolates of the causal pathogen M. cannonballus i.e., 1, 3 and 6 that isolated from diseased plants of watermelon collected from El-Sadat (Minufiya), ElNoubariya (Behaira) and El-Arish (Sinai), respectively; were used in these trials. Seeds of watermelon susceptible cv. Giza 1 were soaked in test extracts for 12 hours, then rainzed to dryness for 3 hours.Six seeds were sown in each pot $(25 \mathrm{~cm}$ indiameter and filled with $50 \%$ field soil $+50 \%$ sand) infested with the pathogen inoculum at the rate of $3 \%$ of soil weight.

Five replicates of each treatment were used and eight pots of non-infested soil were used as control. Pots were irrigated and fertilized as usual and data were recorded as mentioned before.

\section{Plant Oils}

Four plant oils, i.e., Garlic, Cinnamon buds, Marjoram and Black pepper were used in three concentrations i.e., 50, 250 and 500 $\mathrm{ppm}$, for testing their efficacy In vitro and In vivo. Inoculums prepared as mentioned before. Oil concentration was emulsified in water and pots treated with it every 2 weeks tell the end of the experiment. The control treatment was prepared as treatments but pots didn't infested. Disease data were calculated after 70 days from sowing, tabulated and statistically analyzed as mentioned before.

\section{Results and Discussion}

Cucurbits are considered group of the most important and widely distributed vegetable crops in Egypt in open field and protected cultivation. Watermelon (Citrullus lanatus L.) is the major vegetable summer crop in commercial fields in Egypt. Watermelon is liable to be attacked by many different pathogens causing large losses in yield i.e., wilt, sudden wilt, downy \& powdery mildews and others. Watermelon wilt comprises group diseases that have almost similar symptoms, i.e., Fusarium wilt, Verticillium wilt and sudden wilt disease that cause by the fungus $M$. cannonballus. These diseases can take the form of crown rot, root rot, sudden death, Monosporascus root rot/ vine decline, wilt and vine collapse (Bruton et al., 2000).

Sudden wilt disease attacks watermelon plants. Diseased samples were collected from six governorates in Egypt i.e., Minufiya (Sadat), Ismailiya (El-Kassassin), Behaira (El-Noubariya), Dakahliya (Belkas), Alexandria (El-Amriya), and Sinai (ElArish). Isolation of the causal organisms was carried out from diseased watermelon plants showing typical symptoms of sudden 
wilt disease that collected from open fields. $M$. cannonballus was isolated from all materials that collected from the above mentioned six governorates open fields. However, the primary diagnostic sign of the pathogen is the formation of black, spherical, erumpent perithecia on the roots, easily visible with the unaided eye or hand lens. Perithecia are the sexual reproductive structures of the fungus $M$. cannonballus. Perithecia produce large number of distinctive, spherical thick-walled ascospores (Martyn and Miller, 1996). These ascospores can be detected and quantified in the soil by a physical extraction method based on a sucrose centrifugation technique (Stanghellini et al., 1996). Identification of the M. cannonballus isolates were confirmed at Agric. Botany Dept., Fac. of Agric., Minufiya University. One isolate of $M$. cannonballus was selected from the collection of the identified fungal isolates of each of the six districts belonging to the above mentioned six governorates as isolates 1 to 6 and involved in the next studies. (Martyn et al., 1992 and 1996; Alcantara, 1997; Khalifa et al., 2008; ElDesouky et al., 2009 and Silva et al., 2010).

\section{Pathogenicity Tests}

Six isolates of $M$. cannonballus were tested in pots experiment under greenhouse conditions by inoculating with each of them against the susceptible watermelon cultivar (Giza 1) to define the most virulent isolates causing sudden wilt symptoms on the plants. Data in Table (1) indicate that, all six tested isolates of the fungus $M$. cannonballus were pathogenic to watermelon plants. Three isolates, i.e., 6 (Sinai), 1 (Sadat) and 3 (ElNoubariya), revealed as the most aggressive between the six tested isolates (95.90, 90.33 and $86.67 \%$ sudden wilt plants (SW), respectively) and $(88.35,84.00$ and $80.00 \%$ disease severity index (DI), respectively).
Significant differences were noticed between all tested six isolates in disease parameters on tested cultivars as compared to control treatments. These results confirmed results obtained by El-Saiedy, 2003; Khalifa et al., 2008 and El-Desouky et al., 2009. All tested isolates were virulent and cause severe sudden wilt symptoms. Plants of the same watermelon genotype showed different reactions particularly when infection due to different pathogen isolates. Therefore, a disease scale including different infection types was used to evaluate the disease infection. In addition, due to the extensive use of the agricultural soil which leads to the accumulation of the infection units, effective methods for controlling the disease should be considered. Also, soil treatments can be done to control the soil pathogenic fungi.

\section{Disease Control Experiments}

\section{Studies In vitro}

\section{Plant extract}

Six plant extracts were involved in this study i.e., Garlic, Black pepper, Clove bud, Black cumin, Cinnamon and Ginger at concentrations $(1,5$ and $10 \%)$, to test their effect on the fungal linear growth for the most aggressive fungal pathogen isolates from six pathogenic fungi were tested (1, 3 and 6). Data in Fig (1) indicated that all plant extracts were effective on inhibiting the linear growth in Petri dishes for all tested isolates. All plant extract showed a high effect at concentrations (5 and 10\%), there was no significant differences between the effects of two concentrations. The most effective plant extracts at $1 \%$ on linear growth were Garlic $(0.2 \mathrm{~cm})$ on isolate (1) and Clove bud $(0.1 \mathrm{~cm})$ on the three isolates, while the lowest effective plant extract was Cinnamon $(3.4 \mathrm{~cm})$ on isolate $(3)$. 


\section{Plant Oils}

Four plant oils, i.e., Garlic, Cinnamon buds, Marjoram and Black pepper were used in three concentrations i.e., 50, 250 and 500 $\mathrm{ppm}$, for testing their efficacy on the fungal linear growth for the most aggressive fungal pathogen isolates from six pathogenic fungi were tested (1,3 and 6). Data in Fig (2) showed that the most plant oil effect at 50 ppm was the Garlic oil with $(1.6 \mathrm{~cm})$ on isolate (3) and the lowest was Cinnamon bud oil with $(4.5 \mathrm{~cm})$ on isolate (6). The $250 \mathrm{ppm}$ concentration showed the most effective plants oil were the marjoram and garlic with $(0.9$ and $1 \mathrm{~cm})$ on isolate (3), while the lowest effect was the Black pepper oil with $(3.1 \mathrm{~cm})$ on isolate (6). The last concentration 500ppm recorded no growth for Garlic oil, while the lowest was the Black pepper oil with $(1.5 \mathrm{~cm})$ on isolate (6).

\section{Studies In vivo}

\section{Fungicides}

Soil drenching with fungicidal solutions in all used concentrations resulted decreasing in disease parameters in sudden wilt watermelon plants sown in pots and infested by the three aggressive isolates of $M$. cannonballus i.e., 1, 3 and 6 comparing to control treatment plants under greenhouse conditions. Data in Table (2) indicate that, the three tested fungicides controlled sudden wilt of watermelon plants. Also, increasing the concentrations of the three tested fungicides decreased the S.W and D.I \%. The fungicide Bellies was more effective in controlling severity index $\%$ with increasing fungicide concentration at 100, 500 and 1000 ppm, followed by Rizolex T. The most affected isolate was No 3 (the lowest pathogenic one). Significant differences were noticed between isolates, fungicides and used concentration as well as treatments interaction. Similar results were obtained by many researchers by using various fungicides i.e., Cohen et al., (1999); ElKolaly (2003); El-Saiedy (2003; Mansour (2005) and Pivonia et al., (2010)).

\section{Plant Extracts}

The development of alternative control strategies to reduce dependency on synthetic fungicides, plant have ability to synthesize aromatic secondary metabolites, like phenols, phenolic acids, quinines, flavones, flavonoides, flavonols, tannins and coumarins (Cowan, 1999). The components with phenolic structures, like carvacrol, eugenol and thymol were highly active against the pathogens and show antimicrobial effect and serves as plant defense mechanisms against pathogenic microorganisms.

Six aqueous plant extracts i.e., Garlic, Black pepper, Black cumin, Cinnamon, Clove bud and Ginger were selected to study their effects against three aggressive isolates of M. cannonballs i.e., 1,3 and 6 on susceptible watermelon cv. Giza 1 under greenhouse conditions.

Data in Table (3) illustrate that, the tested aqueous plant extracts greatly affected the virulence of the three tested pathogenic isolates on watermelon cv. Giza 1. Significant differences were noticed between all tested plant extracts and their concentrations in infested pots by the three pathogenic isolates under greenhouse conditions.

Regarding to isolate 3 (the least virulence isolate), Garlic extract was recorded the most effective one in S.W. and D.I.\%, followed by clove bud extract in both used concentrations (1 and 5\%), while cinnamon 
extract was recorded the least effective one. The more aggressive isolate No. 6 was recorded highest values of S.W and D.I\% when extracts were applied at 1 and $5 \%$ concentration. Garlic and Clove bud extracts were the most effective, while cinnamon extract was the least effective one, followed by Ginger extract. Significant differences were noticed between tested isolates, aqueous extracts, extract concentrations as well as the interactions between all tested treatments as indicate in Table (3).

These results are in accordance with those obtained by Owoyale et al., (2005); Okereke and Wokocha (2006); Haikal, Nehad (2007) and Viana et al., (2008).

\section{Plant Oils}

Drenching soil with plant oil suspension in all used concentrations decreased sudden wilt disease parameters of watermelon plants cv. Giza 1, that sown in pots infested with one of the three virulent isolates of $M$. cannonballus in comparison to control treatment. Increasing of oil concentration decreased disease parameters gradually.
Garlic oil at 500 ppm great affected S.W.\% and D.I.\% on watermelon cv. Giza 1 plants that infected with isolates No. 1, 3 and 6; it recorded $(16.22,14.35 \& 18.11,19.21$ and $33.11,38.55 \%$, respectively) in comparing to control treatments $(79.66,77.18 \& 86.12$, 80.54 and $81.00,73.45 \%$, respectively as shown in Table (4).

Black pepper oil suspension followed Garlic oil are effecting in decreasing disease parameters. Significant differences were noticed between oil type as well as their applied concentrations.

The chemical composition of the essential oil of Garlic, Cinnamon, Marjoram and Black pepper are known according to previous researches in this field. It is clear that each oil contains many active compounds that affect the sudden wilt disease infection and make a satisfied level of disease control. These results were in agreement with those obtained by Pradhanang et al., (2003), Musa et al., (2007), Kishore and Pande (2007) and Pawar and Thaker (2010).

Table.1 Pathogenicity Test of Six Isolates of Monosporascus Cannonballus against Watermelon Plants cv. Giza 1 under Greenhouse Conditions

\begin{tabular}{|c|c|c|c|}
\hline $\begin{array}{c}\text { Fungal } \\
\text { isolate }\end{array}$ & Location of isolation & $\begin{array}{c}\text { Sudden wilt \% } \\
\text { SW }\end{array}$ & Disease index \% DI \\
\hline 1 & Minufiya (Sadat) & 90.33 & 84.00 \\
\hline 2 & Ismailitya (El-Kassassin) & 56.67 & 46.29 \\
\hline 3 & Behaira (El-Noubariya) & 86.67 & 80.00 \\
\hline 4 & Dakahliya (Belkas) & 80.00 & 75.25 \\
\hline 5 & Alexandria (El-Amriya) & 46.33 & 49.33 \\
\hline 6 & Sinai (El-Arish) & 95.90 & 88.35 \\
\hline
\end{tabular}


Table.2 Effect of Three Fungicides on Sudden Wilt Disease Incidence of Watermelon Plants cv. Giza 1 Incited by Three Aggressive Isolates of Monosporascus cannonballus under Greenhouse Conditions

\begin{tabular}{|c|c|c|c|c|c|c|c|}
\hline \multicolumn{2}{|c|}{ Treatment } & \multicolumn{2}{|c|}{ Isolate 1} & \multicolumn{2}{|c|}{ Isolate 3} & \multicolumn{2}{|c|}{ Isolate 6} \\
\hline \multirow{2}{*}{ Fungicide } & \multirow{2}{*}{$\begin{array}{c}\text { Conc. } \\
\text { ppm }\end{array}$} & \multicolumn{6}{|c|}{ Disease Parameters \% } \\
\hline & & S.W. & D.I. & S.W. & D.I. & S.W. & D.I. \\
\hline Rizolex T & $\begin{array}{c}100 \\
500 \\
1000 \\
\end{array}$ & $\begin{array}{l}51.52 \\
41.49 \\
19.91\end{array}$ & $\begin{array}{l}46.20 \\
42.93 \\
35.12\end{array}$ & $\begin{array}{l}52.64 \\
46.32 \\
15.52\end{array}$ & $\begin{array}{l}38.12 \\
31.39 \\
20.21\end{array}$ & $\begin{array}{l}37.35 \\
35.12 \\
30.57\end{array}$ & $\begin{array}{l}44.18 \\
40.82 \\
32.16\end{array}$ \\
\hline Rofral & $\begin{array}{c}100 \\
500 \\
1000\end{array}$ & $\begin{array}{l}51.36 \\
44.75 \\
40.12\end{array}$ & $\begin{array}{l}50.18 \\
46.11 \\
40.12\end{array}$ & $\begin{array}{l}61.40 \\
53.94 \\
39.12\end{array}$ & $\begin{array}{l}66.16 \\
61.83 \\
40.12\end{array}$ & $\begin{array}{l}52.56 \\
48.12 \\
40.73\end{array}$ & $\begin{array}{l}53.32 \\
48.29 \\
44.18\end{array}$ \\
\hline Bellis & $\begin{array}{c}100 \\
500 \\
1000\end{array}$ & $\begin{array}{l}33.16 \\
28.20 \\
21.19\end{array}$ & $\begin{array}{l}36.15 \\
22.28 \\
18.64\end{array}$ & $\begin{array}{l}25.46 \\
17.67 \\
11.58\end{array}$ & $\begin{array}{l}24.92 \\
17.43 \\
14.28\end{array}$ & $\begin{array}{l}29.16 \\
25.71 \\
24.11\end{array}$ & $\begin{array}{l}33.13 \\
29.18 \\
24.73\end{array}$ \\
\hline Control & & 63.52 & 66.88 & 61.19 & 59.18 & 68.11 & 72.15 \\
\hline
\end{tabular}

$\mathrm{SW}=$ Sudden wilt DI = Disease Index L.S.D. at $5 \%$ between :

1- Isolates $=2.6$

2 - Fungicides $=2.9$

3- - Concentrations $=3.5$

$\begin{array}{ll}\text { Interaction } & 1 \times 2=\mathrm{N} . \mathrm{S} \\ & 1 \times 3=4.2 \\ & 2 \times 3=3.1 \\ & 1 \times 2 \times 7.6\end{array}$

Fig.1 Effect of Some Aqueous Plant Extracts on Monosporascus cannonballus Incited by Three Aggressive Isolates under Laboratory Conditions

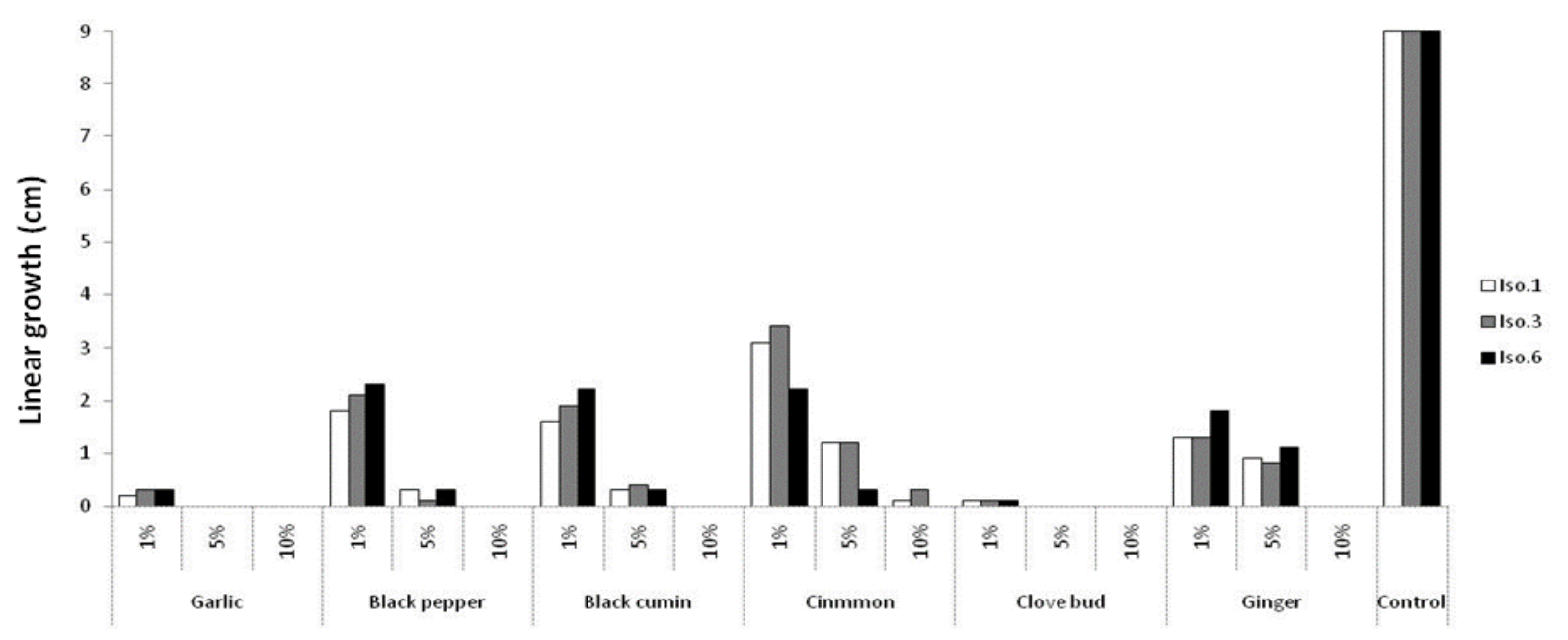

Plant extracts 
Table.3 Effect of Some Aqueous Plant Extracts on Sudden Wilt Disease Incidence of Watermelon cv. Giza 1 Incited by Three Aggressive Isolates of Monosporascus cannonballus under Greenhouse Conditions

\begin{tabular}{|c|c|c|c|c|c|c|c|}
\hline \multicolumn{2}{|c|}{ Treatment } & \multicolumn{2}{|c|}{ Isolate 1} & \multicolumn{2}{|c|}{ Isolate 3} & \multicolumn{2}{|c|}{ Isolate 6} \\
\hline \multirow{2}{*}{$\begin{array}{c}\text { Aqueous plant } \\
\text { extract }\end{array}$} & \multirow{2}{*}{$\begin{array}{c}\text { Conc. } \\
\%\end{array}$} & \multicolumn{6}{|c|}{ Disease Parameters \% } \\
\hline & & S.W. & D.I. & S.W. & D.I. & S.W. & D.I. \\
\hline Garlic & $\begin{array}{l}1 \\
5\end{array}$ & $\begin{array}{l}35.44 \\
1629\end{array}$ & $\begin{array}{l}25.16 \\
2042\end{array}$ & $\begin{array}{l}33.58 \\
1500\end{array}$ & $\begin{array}{l}24.91 \\
1988\end{array}$ & $\begin{array}{l}38.16 \\
1933\end{array}$ & $\begin{array}{l}29.25 \\
2362\end{array}$ \\
\hline Black pepper & $\begin{array}{l}1 \\
5\end{array}$ & $\begin{array}{l}41.62 \\
30.11\end{array}$ & $\begin{array}{l}56.12 \\
24.46\end{array}$ & $\begin{array}{l}38.15 \\
27.75\end{array}$ & $\begin{array}{l}50.08 \\
24.28\end{array}$ & $\begin{array}{l}48.00 \\
35.55\end{array}$ & $\begin{array}{l}52.00 \\
28.18\end{array}$ \\
\hline Black cumin & $\begin{array}{l}1 \\
5\end{array}$ & $\begin{array}{l}41.63 \\
36.20\end{array}$ & $\begin{array}{l}50.53 \\
32.25\end{array}$ & $\begin{array}{l}40.00 \\
33.98\end{array}$ & $\begin{array}{l}49.28 \\
36.15\end{array}$ & $\begin{array}{l}46.14 \\
40.00\end{array}$ & $\begin{array}{l}59.75 \\
37.77\end{array}$ \\
\hline Cinnamon & $\begin{array}{l}1 \\
5\end{array}$ & $\begin{array}{l}62.45 \\
51.72\end{array}$ & $\begin{array}{l}54.11 \\
49.48\end{array}$ & $\begin{array}{l}61.77 \\
45.13\end{array}$ & $\begin{array}{l}55.12 \\
44.65\end{array}$ & $\begin{array}{l}68.12 \\
55.07\end{array}$ & $\begin{array}{l}69.92 \\
65.12\end{array}$ \\
\hline Clove bud & $\begin{array}{l}1 \\
5\end{array}$ & $\begin{array}{l}30.32 \\
17.12 \\
\end{array}$ & $\begin{array}{l}24.79 \\
18.75 \\
\end{array}$ & $\begin{array}{l}28.55 \\
15.46 \\
\end{array}$ & $\begin{array}{l}23.29 \\
16.11 \\
\end{array}$ & $\begin{array}{l}35.14 \\
18.98\end{array}$ & $\begin{array}{l}27.74 \\
21.00\end{array}$ \\
\hline Ginger & $\begin{array}{l}1 \\
5\end{array}$ & $\begin{array}{l}41.65 \\
35.12\end{array}$ & $\begin{array}{l}50.12 \\
33.11\end{array}$ & $\begin{array}{l}40.48 \\
32.28\end{array}$ & $\begin{array}{l}48.53 \\
23.55\end{array}$ & $\begin{array}{l}49.93 \\
46.17\end{array}$ & $\begin{array}{l}57.00 \\
41.88\end{array}$ \\
\hline Control & & 80.00 & 77.14 & 78.12 & 68.11 & 88.16 & 82.53 \\
\hline
\end{tabular}

SW = Sudden wilt plants

DI $=$ Disease Index

L.S.D. at $5 \%$ between :
1- Isolates $=2.23$
$1 \times 2=2.63$
2- Extracts $=3.11$
$1 \times 3=1.54$
$2 \times 3=1.82$

$1 \times 2 \times 3=3.45$

Fig.2 Effect of Some Plants Oils on Monosporascus cannonballus Incited by Three Aggressive Isolates under Laboratory Conditions

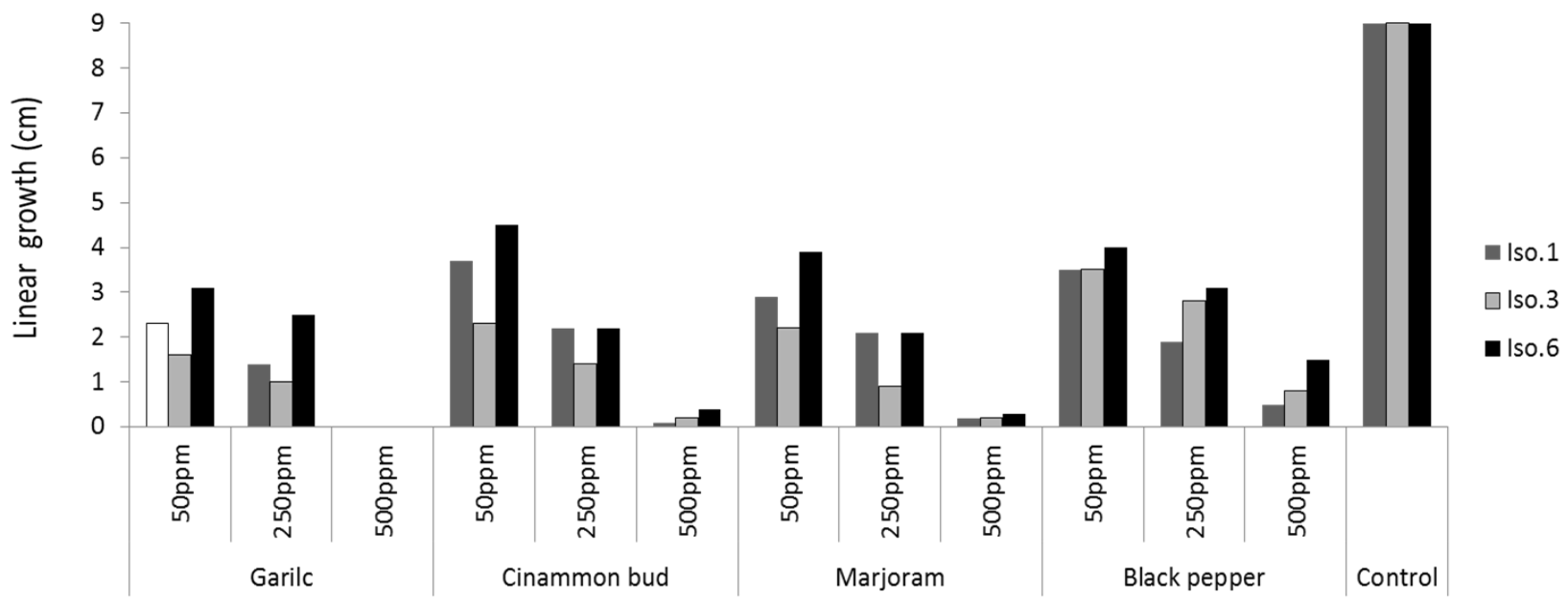

Plants Oils 
Table.4 Effect of Four Plant Oils on Sudden Wilt Disease Incidence of Watermelon cv. Giza 1 Incited by Three Aggressive Isolates of Monosporascus cannonballus under Greenhouse Conditions

\begin{tabular}{|c|c|c|c|c|c|c|c|}
\hline \multicolumn{2}{|c|}{ Treatment } & \multicolumn{2}{|c|}{ Isolate 1} & \multicolumn{2}{|c|}{ Isolate 3} & \multicolumn{2}{|c|}{ Isolate 6} \\
\hline \multirow{2}{*}{ Plant oil } & \multirow{2}{*}{$\begin{array}{c}\text { Conc. } \\
\text { ppm }\end{array}$} & \multicolumn{6}{|c|}{ Disease Parameters \% } \\
\hline & & S.W. & D.I. & S.W. & D.I. & S.W. & D.I. \\
\hline \multirow{3}{*}{ Garlic } & 50 & 43.56 & 40.12 & 36.19 & 32.21 & 40.22 & 45.26 \\
\hline & 250 & 33.77 & 29.88 & 28.25 & 30.68 & 40.00 & 40.39 \\
\hline & 500 & 16.22 & 14.35 & 18.11 & 19.21 & 33.11 & 38.55 \\
\hline \multirow{3}{*}{$\begin{array}{l}\text { Cinnamon } \\
\text { bud }\end{array}$} & 50 & 41.20 & 39.16 & 38.98 & 35.73 & 43.93 & 49.11 \\
\hline & 250 & 36.55 & 40.45 & 30.22 & 27.18 & 40.14 & 44.65 \\
\hline & 500 & 30.14 & 27.56 & 26.75 & 21.25 & 39.11 & 40.21 \\
\hline \multirow{3}{*}{ Marjoram } & 50 & 46.35 & 41.91 & 51.62 & 50.55 & 44.18 & 45.22 \\
\hline & 250 & 42.73 & 39.18 & 44.11 & 43.25 & 36.53 & 36.15 \\
\hline & 500 & 26.18 & 33.82 & 40.28 & 30.22 & 28.41 & 30.12 \\
\hline \multirow{3}{*}{ Black pepper } & 50 & 35.16 & 41.98 & 27.33 & 30.12 & 36.11 & 46.82 \\
\hline & 250 & 30.75 & 36.14 & 22.64 & 26.95 & 40.12 & 38.74 \\
\hline & 500 & 20.12 & 22.25 & 18.35 & 20.12 & 31.75 & 33.74 \\
\hline control & & 79.66 & 77.18 & 86.12 & 80.54 & 81.00 & 73.45 \\
\hline
\end{tabular}

SW = Sudden wilt plants

L.S.D. at $5 \%$ between :

1 - Isolates $=$ N.S.

2- Plant oils $=2.4$

3- Concentrations $=2.2$
DI = Disease Index

$1 \times 2=$ N.S

$1 \times 3=3.5$

$2 \times 3=$ N.S
The essential oils of garlic can be used as an alternative to synthetic pesticides, which allows better managing pests resistant to synthetic and mitigating their adverse effects on the health of users and consumers (Douiri et al., 2013).

The present study demonstrated that plant extracts and plant oils such as Garlic and Cinnamon had considerable effect on the growth rate and disease parameters of $M$. cannonballus, our results are in agree with those obtained by ( Hatamleh et al. 2014) who recorded that Garlic plant extract was effective against Fusarium solani, also (Okigbo et al.2009) evaluated the fungicidal activity of Garlic on some phytopathogenic fungi such as Penicillium oxalicu , F.solani ,Aspergillus niger and F.oxysporum. Avasthi et al., 2005, pointed out that Garlic extract inhibits $100 \%$ of the mycelia growth of $A$. niger. Bowers and Locke,2000, tested the antifungal activity of Garlic extract against the mycelial growth and spore germination of $F$. solani. This antifungal activity of Garlic possibly related to the organosulphur compounds including allicin (Hovana et al. 2011).

Garlic contains some sulphur - containing compounds such as allicin, ajoene, diallysulphide, dithin, s-allulcysteine (Cavallito et al.1945 and Ross et al.2000). These compounds showed better antifungal activity than both antibiotics streptomycin and ampicillin (Ilic et al.,2012). Durairaj et al., 2009 showed that allicin exhibits its antimicrobial activity mainly by immediate 
and total inhibition of RNA synthesis, also, Garlic extract is considered to inhibit cell wall synthesis because it inhibits transpeptidation enzymes involved in crosslinking.

Monteiro et al., 2013 demonstrated that Cinnamon was effective against the mycelia growth and spore germination of Botrytis cenerea \& Alternaria alternate, also Hadi and Kashefi, 2013 showed that Cinnamon extract was effective against Fusarium oxysporum. Al-Taisan et al., 2014, found that the Cinnamon oil inhibit the mycelial growth of Sclerotinia sclerotiorum. The activity of Cinnamon could be attributed to the presence of cinnamic aldehyde and 2propenal,3-phenyl (Hadi and Kashefi, 2013). Boniface et al., 2012 tested the antimicrobial activity of Cinnamon oil and found that the essential oil had fungicidal activity against Penicillium digitatum and Fusarium oxysporum.

\section{References}

Aegerter, B.J.; Gordon, T.R. and Davis, R.M. (2000). Occurrence and pathogenicity of fungi associated with melon root rot and vine deeline in California. Plant Dis. 84: 224-230.

Alcantara, T.P.; Rasmussen, S.L. and Stanghellini, M.F. (1997). Bological characterization of Monosporascus cannonballus. Phytopathology. 87: 53.

Avasthi, $\quad$ S.; $\quad$ Guatam.A.k.and Bhadauria.(2005). Antifungal activity of plant products against Aspergillus niger: A potential application in the control of a spoilage fungus.Int.J., 2:53-55

Boniface, Y.; Philippe, S.; de Lima, H.R.; Pierre, N.J. ; Alian, A.G.; Fatiou, T. and Dominique, S. (2012). Chemical composition and antimicrobial activities of Cinnamomum zeylanicum Blume dry leaves essential oil against food-borne pathogens and adulterated microorganisms. Int. Res. J. Biol. Sci, 1:18-25.

Bowers,J.H. and Locke, J.C.(2000). Effect of botanical extracts on the population density of Fusarium oxysporum in soil and control of Fusarium wilt in the greenhouse. Plant Dis. 84:300-305.

Bruton, B.D.; Garcia-Jimenez, J.; Armengol, J. and Popham, T.W. (2000).Assessment of virulence of Acremonium cucurbitacearum and Monosporascu scannonballus on Cucumis melo. Plant Disease, St. Paul. 84: 907-913.

Cavallito, C.J; Bailey, J.H and Allicin, B.J.(1945). The antibacterial principle of Allium sativum.III. Its precursor and "essential oil" of garlic. J. Am. Chem. Soc. 67:1032-3.

Cohen, R.; Pivonia, S.; Shtienberg, D.; Edelstein, M.; Raz, D.; Gerstl, Z. and Katan, J. (1999). The efficacy of fluazinam in suppression of Monosporascus cannonballus, the causal agent of vine decline of melons. Plant Dis. 83: 1137-1141.

Cowan, M.M. (1999). Plant products as antimicrobial agents. Clinical Microbiology Reviews, 12: 564-582.

Douiri, L.F.; Boughdad, A.; Assobhei, O. and Moumni, M. (2013). Chemical composition and biological activity of Allium sativum essential oils against Collosbruchus maculates. J. of Eviron Sci., Toxicology and Food Technology. 3: 30-36.

Durairaj, S.; Srinivasan,S. and Lakshmanaperumalsamy,P.(2009). In vitro antibacterial activity and stability of garlic extract at different $\mathrm{pH}$ and temperature. Electron. J. 
Biol., 5:5-10.

El-Desouky, S.M. and El-Wakil, A.A. (2003). Occurrence of Monosporacus root rot and vine decline of cantaloupe and watermelon in Egypt. Egypt J. of Phytopath. 34 (1) 12-18.

El-Desouky, S.M., Awad, M.A. and Majdah, M.Y. Al-Tuwaijri (2009). Distribution of Monosporascus in Egypt. J. Agric. Sci. Mansoura Univ., 34 (6): 6805-6815.

El-Kolaly, G.A.A. (2003). Pathological studies on root rot and crown rot strawberry in Egypt. Ph.D. Thesis. Fac. of Agric., Cairo Univ., pp 151.

El-Saiedy, A.M. (2003). Studies on wilt disease of cucumber under greenhouse conditions. M.Sc. Thesis, Fac. of Agric., Minufiya Univ., pp 90.

Gennari, S.; Mirotti, A. and Sportelli, M. (1999). Monosporascus cannoballus on watermelon. Infrmatore Fitopatologico (Italy). 49: 38-40.

Hadi, M. and Kashefi, B.(2013). Study on effect of some medicinal plant extracts on growth and spore germination of Fusarium oxysporum schlecht. In vitro. Am. Eurasian J. Agric. Environ. Sci., 13:581-588.

Haikal, Z. Nehad (2007). Improving biological control of Fusarium root rot in cucumber (Cucumis sativus) by allelopathic plant extracts. International $J$. of Agric. and Biology. 9: 459-462.

Hatamleh, A.A.; Bahkali, A.H.; ElSheshtawi, M.; El-Metwally, M.A. and Elgorban, A.M. (2014). Inhibitory influence of plant extracts on soil borne fungi infecting muskmelon ( Cucumis melo L.). Int. J. Pharmacol., 10: 322-327.

Hovana, E.I.K.; James, U.S.; James, E.; Egbobor. E.M.; Egba, A.G.; Eta, E.S. and Nwakaku,O.A.(2011).
Antibacterial and phytochemical studies of Allium sativum. N.Y. Sci. J. 4:123-128.

Ilic,D.;Nikolic,V.; Ciric,A.; Sokovic,M,and Stanojkovic,T.(2012). Cytotoxicity and antimicrobial activity of allicin and its transformation products. J. Med. Plants Res.,6:59-65.

Karlatti, R.S.; Abdeen, F.M. and Al-Fehaid, M.S. (1997). Report of Monosporascus cannonballus on melons in Saudi Arabia. Plant Dis. 81: 1215 .

Khalifa, E.Z.; Awad, M.A.; Mostafa, M.M. and El-Saiedy, A.M. (2008). Monosporascu scannonballus, the causal organism of cucumber sudden wilt and its control. I.C.P.P., Aug. 2008.

Kishore, K. and Pande, S. (2007). Evaluation of essential oils and their components for broad-spectrum activity and control of late leaf spot and crown rot diseases in peanut. (Abstract) Plant Disease. 91: 375.

Mansour, A.S.(2005). Pathological studies of wilt disease of strawberry in Egypt. Ph.D. Thesis, Fac. of Agric., Moshtohor, BenhaUniv., pp 157.

Martyn, R.D. and Miller, M.E. (1996). Monosporascus root rot and vine decline: An emerging disease of melons worldwide. Plant Dis. 80: 716-725.

Martyn, R.D.; Batten, J.S.; Park, Y.J. and Miller, M.E. (1996). First report of Monosporascus root rot and vine decline of watermelon in Mexico. Plant Dis. 80: 1430.

Martyn, R.D.; Lovic, B.R.; Maddox, D.A.; Germash, A. and Miller, M.E. (1994). First report of Monosporascus root rot/ vine decline of watermelon in Tunisia. Plant Dis. 78: 1220.

Martyn, R.D.; Mertely, J.G.; Miller, M.E.; 
Katsar, C.D. and Baasiri, R. (1992). Morphology and germination of Monosporascus cannonballus ascospores. Phytopathology. 82: 1115.

Monteiro, F.P.; Ferreira, L.C.; Silva, J.L. Pacheco,L.P. and Souza, P.E. (2013). Influence of plant extracts and essential oils against panama disease (Fusarium oxysporum f.sp. cubense) in banana seedlings. J. Agric. Sci., 4: 63-74.

Musa, M., Chalchat, J.C., Arslan, D., Vocational, A.G. and Cnver, A. (2007). Comparative essential oil composition and antifungal effect of bitter fennel (Foeniculum vulgare spp piperitum) fruit oils obtained during different vegetation. J. of Medicinal Food. 9: 552-561.

Mutwally, H.M.A.; Omar, M.A. and Bidaiwy, M. (2010). Microsporum gallinae growth response to some plant extracts. http://uqu.edu.Sa/page/ar/2053.

Okereke, V.C. and Wokocha, R.C. (2006). Effect of some tropical plant extracts, Trichoderma harzianum and captan on the damping-off disease of tomato induced by Sclerotium rolfsii. Agric. J. 1: 52-54.

Okigbo, R.N.; Okorie, R.E. and Putheti, R.R.(2009). In vitro effect of garlic (Allium sativum L.) and African Basil ( Ocimum gratissimum L.) on pathogens isolated from Rotted cassava roots. Interciencia 34: 742747.

Owoyale, J.A.; Olatunji, G.A. and Ogutoye, S.O. (2005). Antifungal and antibacterial activities of an alcoholic extract of Seena alata leaves. J. Appl. Sci. Environ. 9: 105-107.

Pawar, V.C. and Thaker, V.S. (2010). Evaluation of the anti Fusarium oxysporum f.sp cicer and anti
Alternaria porri effects of some essential oils. World J. of Microbiology and Biotechnolohy. 23: 1099-1106.

Pivonia, S.; Gerstl, Z.; Maduel, A.; Levita, R. And Cohen, R. (2010). Management of Monosporascus sudden wilt of melon by soil application fungicides. European J. of Plant Pathology. 128: 201-209.

Pollack, F.G. and Uecker, F.A. (1974). Monosporascus cannonballus an unusual ascomycete in cantaloupe roots. Mycology. 66: 346-349.

Pradhanang, P.M.; Momol, M.T. and Olson, S.M. (2003). Effects of plant essential oils on Ralstonia solanacearum population density and bacterial wilt incidence in tomato. Plant Disease. 87: 423.

Ross, Z.M.; Maslin, D.J. and Hill, D.J.(2000). The effect of steam distilled garlic oil on lactic acid and other enteric bacteria. $4^{\text {th }}$ symposium on European Microbiological Societies. FEMS Microbiol. Rev. $12: 137$

Sarpeleh, A. (2008). The role of Monosporascus cannonballus in melon collapse in Tran. Australasian Plant Disease Notes. 3: 162-164.

Silva, K.J.B.; Cordieto, A.G.; Nogueira, D.R.S. and Junior, R.S. (2010). Monosporascus cannonballus, causal agent of melon collapse or sudden wilt. Revista Verde (Mossoro-RN-Brasil) 5: 11-18.

Stanghellini, M.E.; Kim, D.H. and Rasmussen, S.L. (1996). Ascospors of Monosporascus cannonballus: Germination and distribution in cultivated and desert soils in Arizona. Phytopatholog. 86: 509514.

Suqin, B. and Bin, B. (2010). First report on Monosporascus cannonballus on 
melon in China Mainland. Plant Protection. 36: 116-119.

Tsair-Bor, Y. and Shang-Tzen, C. (2008). Synergistic effects of cinnamaldehyde in combination with eugenol against wood decay fungi. Bioresource Technology. 99: 232236.
Viana, M.G.; Albuquerque, C.C.; Medeiros, E.V.; Viana, F.A. and Silva, K.M.B. (2008). Evaluation of the fungicide of ethanolic extracts of Senna alata against Monosporascus cannonballus Cienc. Agrotec., Lavras, 32: 13781393.

\section{How to cite this article:}

Hosam M. Awad. 2016. Evaluation of Plant Extracts and Essential Oils for the Control of Sudden Wilt Disease of Watermelon Plants. Int.J.Curr.Microbiol.App.Sci.5(5): 949-962. doi: http://dx.doi.org/10.20546/ijcmas.2016.505.100 